\title{
Stability Phenotypic Characters and The Scent of Gama Melon Parfum Cultivar
}

\author{
Sigit Dwi Maryanto ${ }^{1}$, Rini Etika Ranis ${ }^{1}$, and Budi Setiadi Daryono ${ }^{1}$
}

\begin{abstract}
Parfume is one of the cosmetic product and its use is consistent. High prices of cosmetic product cause dependence on imported product. Innovative research is needed to reduce dependence on imported product. Melon is one of the potential horticultural crops to be developed in plant breeding. Gama Melon Parfum cultivars has strong of fragnant so its potentially to be used as parfume material. Research on morphological characters to support of Gama Melon Parfum as superior cultivar. The research aims to determine the level of stability of phenotypic characters and aroma of melon Gama Melon Parfum cultivar. Research methods was cultivated Gama Melon Parfum in Kebun Pendidikan Penelitian dan Pengembangan Pertanian (KP4) UGM Yogyakarta. Furthermore, the phenotypic characters was observed consist of qualitative and quantitative characters. The methods of sampling used Randomize Complete Block Design (RCBD) and quantitative phenotypic characters were analyzed using software PKBT-STAT-2. The result of qualitative characters on Gama Melon Parfum cultivars has oblate shape, small size, yellow-orange skin of colour with 9-10 lobes and longitudinal, white of flesh colour, crunchy texture, bitter taste, zero score of nett (not netted), strong of fragnant, and has spesific qualitative characters called turbin. Quantitative characters on Gama Melon Parfume cultivars consist of average weight of 160 gram; circumference of 21,8 cm; horizontal diameter of 6,89 cm; vertical diameter of 6,44 cm; thick skin of $1 \mathrm{~mm}$, thick flesh of 1,06 cm; the number of seed of 200-300; weight of 100 seed of 1,74 gram; harvest 63-65 day after cultivate; and 17 days of storage time.
\end{abstract}

Keywords—Cucumis melo L., Gama Melon Parfum, Phenotypic character.

\section{INTRODUCTION}

$\mathrm{P}$ otential market of cosmetic products in Indonesia is very high. Based on data from the International Cosmetics Club, cosmetic products import reached USD 4-10 billion per month. Perfume is one of the cosmetic products generally used by the people and their use is consistent. Its dependency on imported products caused cosmetics prices became high ${ }^{[12]}$. Research innovative to the types of plants that have the potential as a cosmetic material needed to reduce dependence of imported products.

Melon (Cucumis melo L.) is one of the fruits, member of Cucurbitaceae, with potential to be developed in plant breeding $^{[20]}$. Melon plants included in the divisio of Spermatophyta (seed plants), sub-divisio of Angiospermae because these plants have seeds covered in leaves or seeds in the fruit, class of Dicotyledoneae and sub-class of Sympetalae because has flowers with corolla attached each other ${ }^{[19]}$.

Melon plants have a tap-root that consists of the main root (primary), lateral roots (secondary), and root fibres (tertiary) are out of the lateral roots. Primary root length to the base of the stem has reached $15-20 \mathrm{~cm}$ and can strongly penetrate into the ground about 1-20 meters. Primary root cortex is involved in the growth and development of secondary roots ${ }^{[19]}$. Secondary roots emerge from the primary root. Secondary roots on Cucurbitaceae grow near the soil surface and can get into the soil up to $60 \mathrm{~cm}$. On Cucurbitaceae, lateral roots can spread and grow about 35-45 cm around the trunk or above ground stem ${ }^{[6]}$.

Melon has green stems with slightly pentagonal shape with a grooved indentation 3-7 and 8-15 cm diameter ${ }^{[23]}$. Melon plant stems are hairy and sections were attached

${ }^{1}$ Sigit Dwi Maryanto, Rini Etika Ranis, and Budi Setiadi Daryono are with Departement of Biology, Faculty of Biology, Universitas Gadjah Mada, Yogyakarta, Indonesia. E-mail: sdmaryanto@yahoo.com; rinietikaranis@ymail.com; bs_daryono@yahoo.com. petiole. The stem is herbaceous and this type is suitable for vines or climbing. Branching consists of primary branches and secondary branches with a length of $15 \mathrm{~m}$. The main stem can grow to about $45 \mathrm{~cm}$ without branching and only produce flowers with 3-5 stamens. Cucurbitaceae have bicolateral type of carrier vessel, phloem located inside and xylem located outside, scattered in cortex and arranged in two rings surrounding the central cylinder or pith cavity. The stem anatomy makes Cucurbitaceae be more flexible in bringing nutrients ${ }^{[19]}$.

Cucurbitaceae have arranged alternate leaves (alternate), 5 lobes and without stipules ${ }^{[6]}$. The type of flower on melon has actinomorphic, generally unisexual, perinthium short, composed of 3-6 sepals and 3-6 petals to form corolla with yellow colour ${ }^{[16]}$. Number of male flowers more than female flowers ${ }^{[5]}$.

Melon plants have radial symmetry flowers, monoecious. The flower of melon is tetracyclic, and the flower has five parts. The tip of the crown leaves arranged like a valve. Number of stamens are 5, attaches to each other (rarely free); anthers has two spaces. Anthers stalk together with stigma form fork-like shape. Ovary sink, most have three lobes and each lobes have two bends placenta came out with most of the large number ovule (sometimes only one on a particular species), each of the two membranes makes the seed coat $^{[6]}$.

By longitudinal section viewing, melon fruit consists of skin, pulp and seeds. Fruit skin is not too thick, only 1-2 $\mathrm{mm}$, and hard. Fruit of skin consists of the epidermis, mesodermis and endodermis. Inside the cavity there is a bunch of melon seeds wrapped in white placenta. Melon seeds are generally light brown with an average length of $0.9 \mathrm{~mm}$ and a diameter of $0.4 \mathrm{~mm}$ with a number of about 500-600 melon seeds ${ }^{[6]}$.

Melon classified into two types, namely-netted melon and winter-melon. Type of Netted-Melon has the characteristics of hard-skinned fruit, veined and shaped like net, relatively more fragrant aroma compared with winter-melon; ripening 75-90 days, durable and long 
lasting to be stored. Type of Winter-Melon has the characteristics of smooth-skinned fruit, not shiny and fragrant fruit aromas; fruit to ripen slowly 90-120 days; easily rot and easily damaged to be stored; this types of melon is often used as an ornamental plant ${ }^{[7]}$.

Plant breeding is an attempt to obtain superior varieties through crossing method and utilization of agriculture technology ${ }^{[4]}$. Terms of superior plants has high ability to reproduce, the quality of a good harvest, and have certainty yields ${ }^{[22]}$. Melon plant breeding applications developed in many Asian countries such as India, Japan, Korea, China, and Thailand to produce superior varieties $^{[2]}$.

Stages of plant breeding include collection, at the earliest stages, plant breeders collect various plant varieties derived from local plant varieties, introduced varieties and selection results from other countries, varieties of central origin and new varieties of genetically modified products, e.g. mutations ${ }^{[13]}$. Seed collections were obtained from several countries including India, Japan, Turkey, Taiwan, RRC, Thailand, and Malaysia. Seed collections were also taken from local varieties and introduced varieties. Seed collection is purposed as a germplasm that functioned as source of donor genes in plant breeding programs ${ }^{[4]}$.

In second stage, characterization, is a step in identifying genotype and phenotype characteristics of crop (parental and offspring) were collected. In the process of characterization performed a variety of methods to identify, for example, using a numerical classification, chemical or molecular. The goal is to determine the genetic diversity of plants collected thus identified and characterized genes known to be excellent character, original and disease resistance. So, may be the development and improvement of desired plant in next stage ${ }^{[4]}$.In third stage, assembly process is performed melon plant consists of two components, namely the selection and cross breeding. Selection is the selection of varieties that will be used to do as the parental in plant breeding program. Selected plant varieties derived from descriptive of data collection from germplasm so obvious as to be crossed genes are known of characters, both genotype and phenotype ${ }^{[4]}$.

In last stage, release of a variety can be done after going through various certification test. Seed to be certified is derived from a seed varieties, which is a variety that has gained approval and recognition of the advantages. Varieties submitted must conform of several requirement, that is new or previously unknown (novelty), has a characteristic and distinctive mark (distinct), uniform and showed stability on the location and the next generation (stability). The certification process conducted by field test and laboratory test ${ }^{[4]}$.

Melon plant breeding has been carried out in 2011 and produced melon cultivars "Gama Melon Perfume". Gama Melon Perfume is a result of a crossing over between $P$ NO3 and $\delta$ MR5. The purpose of this study to determine the level of stability and uniformity of phenotype character and aroma of Gama Melon Perfume cultivar.

\section{METHOD}

\section{A. Material and Equipments}

Materials used in this study is the seed melon of Gama Melon Parfume cultivars obtained from Laboratory of Genetics Faculty of Biology, various types of fertilizers in the form of basal fertilizer (ZA, KCI and TS), and liquid fertilizer (NPK brand pearls and ZA), and insecticides.

The equipment used in this study cover such as plastic mulch beds, horizontal and vertical strut melon plants to propagate straight from bamboo, palm leaf midrib and acacia trees, rope as a binder branches, lateral, camera, scales for weigh fruit and melon seeds, medline to measure the circumference of the fruit, and plastic for seed.

\section{B. Cultivation}

The seed of Gama Melon Parfume cultivar was germinated and planted into polybag containing growing media. After the age of 7 days, grown on land that has been made beds and mulch and bamboo fitted with a spacing along of plants were $50 \mathrm{~cm}$. Treatment plants to provide enough fertilizer and irrigation. Treatment is also done by cutting of lateral branches melon plant. In one of melon plants were selected as 8-10 pieces. Melon harvested at the age of 63-65 days after planting in the field.

\section{Sampling}

The sampling method using Random Complete Block Design (RCBD) with the number of 50 pieces ${ }^{[11]}$. Samples were observed phenotype character consisting of quantitative phenotypic characters in melon observed according to the rules of PVP (plant variety protection) include weight of fruit; circumference of fruit; horizontal diameter; vertical diameter; thick of skin, thick of flesh; the number of seed; weight of 100 seed; harvest or rippening; and days of storage time. As for the qualitative phenotype includes fruit shape, fruit color, groove fruit color, flesh color, fruit shape cavity longitudinally, net (net), fruit flesh texture, water content, taste the fruit, fruit aroma, seed color and seed shape, lobes, fragnant, and has spesific qualitative characters called turbin ${ }^{[8]}$.

\section{Analysis}

Qualitative character analysis based on International Plant Genetic Resource Institute (IPGRI ${ }^{[10]}$. While the quantitative character using software PKBT-STAT-2 ${ }^{[9]}$.

\section{RESULT AND DISCUSSION}

The process begins with a seed assembly crosses to produce the desired characters, followed by the selection and purification, then adaptation test, and multiseason multilocation test. Gama Melon Perfume cultivar is a result of a crossing over between $\bigcirc \mathrm{NO} 3$ and $\delta$ MR5 (figure 1). Testing was conducted to determine planting adaptation, stability and the results are promising lines tested, in order to get new varieties are high yielding and 
well adapted $^{[4]}$. Adaptive testing done also aims to determine the stability and uniformity of phenotype characters of Gama Melon Perfume cultivar ${ }^{[20] .}$

Adaptation test is done by planting Gama Melon Perfume cultivars and observed of qualitative phenotypic characters. Analysis of quantitative characters using software PKBT-STAT-2 ${ }^{[9]}$. For quantitative phenotypic characters in melon observed and compared in accordance with the rules of Plant Variety Protection (PVP) weight of fruit; circumference of fruit; horizontal diameter; vertical diameter; thick of skin, thick of flesh; the number of seed; weight of 100 seed; harvest or rippening; and days of storage time ${ }^{[10]}$. While analysis of qualitative character phenotype were used scoring method and compared with observations based on International Plant Genetic Resource Institute (IPGRI). As for the character of qualitative phenotypes include fruit shape, fruit color, groove fruit color, flesh color, fruit shape cavity longitudinally, net (net), fruit flesh texture, water content, taste the fruit, fruit aroma, seed color and seed shape, lobes, fragnant, and has spesific qualitative characters called turbin ${ }^{[8]}$.

The result of research were qualitative characters consist of oblate shape, small size (Figure 2), yelloworange skin of colour with 9-10 lobes and longitudinal lines (Figure 3), white of flesh colour (Figure 4), crunchy texture, bitter taste, zero score of nett (not netted), strong of fragnant, and has spesific qualitative characters called turbin (Table 1).

Shape of fruit included of qualitative character that is controlled by a single gene means that the shape of the fruit is regulated by a single dominant or recessive gene. The shape of Gama Melon Parfum was observed using scorring method that is oblate. Oblate has ratio lines of fruit $1,0: 1,0$ (horizontal : vertical) ${ }^{[14]}$. Oblate form and small size likely inherited from female parent that is $q$ NO3. Gama Melon Parfum has not netted and strong fragnant. This is indication that include type of winter melon $^{[7]}$. Gama Melon Parfum also has specific character called turbin located in the bottom of fruit (Figure 2).

The result of research were quantitative characters consist of average weight of 160 gram; circumference of $21,8 \mathrm{~cm}$; horizontal diameter of $6,89 \mathrm{~cm}$; vertical diameter of $6,44 \mathrm{~cm}$; thick skin of $1 \mathrm{~mm}$, thick flesh of $1,06 \mathrm{~cm}$; the number of seed of 200-300; weight of 100 seed of 1,74 gram; harvest 63-65 day after cultivate; and 17 days of storage time (Table 2).

Phenotype character is the appearance of the outside or other characteristics of an individual that can be observed or measured. Phenotype can be observed based on quantitative and qualitative character. Qualitative characters are traits that are not visible and can be measured in units of a certain size. Qualitative characters also is not continuous and there are classes distinctly different phenotypes. Qualitative characters are controlled by a single gene ${ }^{[13]}$.

Quantitative characters is a character that can be measured, continuous manifold, forming phenotype spectrum and if large enough populations often a normal curve form. Quantitative character controlled by several genes (polygenic) and each gene gave little influence. A polygenic genes, each of which showed little effect on the appearance of the phenotype but can as complement to result in quantitative changes that can be observed ${ }^{[1] \text {. }}$

Quantitative character is influenced by the interaction between the genotype with the environment. Some environmental factors that affect to quantitative characters include the availability of water, nutrients, temperature, light intensity, soil moisture, etc. In the quantitative character types are genes that control multiple genes (polygenic). Multiple genes (polygenic) will interact with a variety of environmental factors that affect the growth of a plant. In addition to environmental factors, there are also other factors that affect the formation of phenotype that is the factors in cells that are not easily measured. The interaction between genotype and environmental factors will affect the quality and quantity of the growth of a plant. Quality and quantity of this plant is referred to as the phenotype $\mathrm{e}^{[1]}$.

The dry season is a suitable season for the growth and development of melon plants because these plants require full sun exposure during its growth. Rainfall intensity are needed by plants melon only 2000 to 3000 $\mathrm{mm} /$ year and require optimum temperature of about 35 to $37.5^{\circ} \mathrm{C}$. Range of humidity suitable are 70 to $80 \%$. While the rainy season is usually very high rainfall with low light intensity, low temperature and high humidity so it is not suitable for cultivation of melon ${ }^{[18]}$.

Melon plants actually require plenty of water to help its growth, but the water should have a neutral $\mathrm{pH}$ range (5.6 to 7.2). Water from rain has acid of $\mathrm{PH}$ so that can interfere with enzymes that act on metabolic processes. The existence of a metabolic disorder causing impaired growth and even cause death. The interaction between the water of rain and genes can affected to the phenotype that appears. Rain water will interfere with the work of several genes that control the phenotype with a way will turn off to genes that affect the expression generated as a result of adaptation are not fixed (non- plastic) ${ }^{[17]}$.

This also occurs in the temperature, humidity of air and humidity of soil. The optimum temperature required of plant for the metabolism process, respiration, diffusion, and other processes during the growth period. Highly temperature can be transpiration process goes very quickly so that the rate of water absorption is also running fast. In the dry season the temperature is relatively high so that the required large of amount of water to offset the high transpiration rate, whereas at low temperatures the rainy season due to low light intensity thus slow the rate of transpiration and water absorption rate is small and the water is not needed in large quantities. In the process of fruit formation required of water and temperature optimum. The excess of water too much can be influenced to the fruit are rot quickly and the temperature is too high or low can be resulting in the formation of fruit is not maximum. The fruit formation in melon is due to the interaction between multiple genes with the environment. Environmental factors will caused to genes in the plant will be turn on or turn off depending on the type of genes ${ }^{[1]}$.

Character of superior from Gama Melon Parfum cultivars that is highly fragrant fruit aromas like perfume. This fragrance is likely to come from the class of terpenoids compounds contained in fruit. Terpenoid types of compounds are likely sesquiterpene class. Sesquiterpenes are a class of terpenes that consist of 
three isoprene units and have the molecular formula $\mathrm{C}_{15} \mathrm{H}_{24}$. Sesquiterpenes can form group-containing acyclic or ring $^{[21]}$.

Sesquiterpene accumulation lasted until the maturity of the fruit, causing the fragrance increased. The fragrant aroma enhancement due to the increasing activity of ethylene. Melon rind color changes from green to brownish yellow due to accumulation of pigment ${ }^{[15]}$..

The existence of a very fragrant aroma has the potential to be used as raw material in a way perfume extraction. Gama Melon Parfume cultivar's can reduce dependence on imported cosmetic products. In addition, this product is relatively safe because it comes from natural ingredients in accordance with modern people's behavior is likely to choose a product that is Go Green or Back to Nature.

\section{CONCLUSION}

Gama Melon Parfume cultivars has stable for phenotype character and flavor. Based on result of qualitative characters on Gama Melon Parfum cultivars has oblate shape, small size, yellow-orange skin of colour with 9-10 lobes and longitudinal, white of flesh colour, crunchy texture, bitter taste, zero score of nett (not netted), strong of fragnant, and has spesific qualitative characters called turbin. Quantitative characters on Gama Melon Parfume cultivars consist of average weight of 160 gram; circumference of $21,8 \mathrm{~cm}$; horizontal diameter of $6,89 \mathrm{~cm}$; vertical diameter of 6,44 $\mathrm{cm}$; thick skin of $1 \mathrm{~mm}$, thick flesh of $1,06 \mathrm{~cm}$; the number of seed of 200-300; weight of 100 seed of 1,74 gram; harvest 63-65 day after cultivate; and 17 days of storage time.

Qualitative phenotype character is controlled by a single dominant or recessive gene that affected the environment, whereas quantitative phenotypic characters are controlled by multiple genes (polygenic) are influenced by the environment.

\section{ACKNOWLEDGEMENT}

I would like to give my best gratitude to Lembaga Penelitian Pengabdian Kepada Masyarakat (LPPM) UGM, and from Kebun Pendidikan Penelitian dan Pengembangan Pertanian (KP4) UGM for Research Grant no. 004/ST/KP4/DIPA/2013.

\section{REFERENCES}

[1]. C.Perin, C. Dogimon, N. Giovinazzo, D. Besomes, L.Guitton, L. Hagen and M. Pitra, "Genetic Control and Linkages of Some Fruits Characters in Melon”, Cucurbit Genetic Cooperative Report, 1999, 22: 16-18.

[2]. B.S. Daryono and Genesiska, "Kebangkitan Pertanian Indonesia”, Penerbit BPFE. Yogyakarta, 2010, p. 11
[3]. B.S. Daryono, S. Somowiyarjo, and K.T.Natsuaki, “Screening for resistance to Kyuri green mottle mosaic virus in various melon”, Plant Breeding, 2005, 124 (4):487-490

[4]. B.S.Daryono, S.D. Maryanto, I.N. Huda, "Kebangkitan Pertanian Indonesia”, Kebun Pendidikan Penelitian Pengembangan Pertanian (KP4) UGM, 2011.

[5]. F. Prajnanta, "Pemeliharaan secara Intensif dan Kiat Sukses Beragrobisnis Melon”, PT Penebar Swadaya, Jakarta, 2004, pp $1-5,8-12$

[6]. G.Tjitrosoepomo,"Taksonomi Tumbuhan Spermatophyta”, Gadjah Mada University Press, Yogyakarta, 1989, pp. 379-380

[7]. G.M.Weihong, "Comparison of Staking and Nonstaking on Melon and Muskmelon (Cucumis melo L.) Production”, ARC Training

[8]. Hindarwati, "Panduan Pengujian Individual Kebaruan, Keunikan, Keseragaman, dan Kestabilan: Melon (Cucumis melo L.). Departemen Pertanian Republik Indonesia: Pusat Perlindungan Varietas Tanaman.hal 8.http://www.ppvt.setjendeptan.go.id. Date Feb 14, 2010

[9]. IPB, "Program PKBT-STAT-2. http://www.pkbt.ipb.ac.id. Date July 12, 2010

[10]. IPGRI, "Minimum Descriptors for Cucurbita spp., Cucumber, Melon, and Watermelon, European Cooperative Programme for Riset Genetic Resource, 2005, p.9

[11]. K.A.Gomez, and A.A.Gomez, "Prosedur Statistik untuk Penelitian Pertanian Edisi kedua”, Penerbit UI Press, Jakarta, pp. 8-87

[12]. Kementrian Perindustrian,”Volume of Export-Import Cosmetics”, http//www.kemenperin.go.id. Date April 27, 2013

[13]. L.V. Crowder, "Genetika Tumbuhan”, Gadjah Mada University Press, Yogyakarta 1986 pp. 366-367, 406-442

[14]. M.Rashidi and M. Syefi, "Classification of fruit shape in cantaulope Using The Analysis Geometrical”, World of Journal Agricultural Science, 2007, 3(6), 735-740

[15]. N. Katzir, R. Harel-Beja, V. Portnoy, G. Tzuri, E. Koren, S. Lev, E. Bar, Y. Tadmor, Y. Burger, E. Lewinsohn, Z. Fei, J.J.Giovannoni, and A.A. Schaffer, "Melon fruit quality: A genomic approach", Proceedings of the IXth EUCARPIA meeting on genetics and breeding of Cucurbitaceae. San Diego. USA, 2008, pp 1-10

[16]. P.H. Davis, and V.H. Heywood. Principles of Angiosperm Taxonomy. Robert E. Krieger Publishing Company Huntington, New York, 1973, pp. 116-119

[17]. P.R. Goldsworty, and N.M. Fisher, “The Physiology of Tropical Field Crops”, Gadjah Mada University Press, Yogyakarta, 1984 pp. 17, 51-69

[18]. R.G.S. Bidwell, "Plant Physiology Second Edition”, Macmillan Publishing Co Inc. New York, 1979, pp 247-266, 385-387, 396

[19]. Robinson and Decker-Walker, "Cucurbits”. Cab International 198 Madison Avenue.New York, USA 1999, pp. 80-90

[20]. S.D. Maryanto and B.S.Daryono, “ The Comparison of Melon (Cucumis melo L.) Phenotypic Characters among Melodi Gama 1, Gama Melon Basket, and Commersial Cultivars Using Multilocation and Multiseason Test”, Proceeding at Pasific Science Congress, Kuala Lumpur, Malaysia. p. 164, May 2011

[21]. V. Portnoy, Y. Benyamini, R.H.Bar, E.,Beja, S. Gepstein, J.J. Giovannoni, A.A. Schaffer, J. Burger, Y. Tadmor, E. Lewinsohn, N. Katzir, "The molecular and biochemical basis for varietal variation in sesquiterpene content in melon (Cucumis melo L.) rinds. Plant Mol Biol, 2008, 66:647-661

[22]. W. Mangoendidjojo, ”Dasar-Dasar Pemuliaan Tanaman”, Kanisius, Yogyakarta, 2003, pp. 30-34

[23]. Y. Alaydrus, “ Pemuliaan dan Pewarisan Sifat Ketahanan terhadap Kyuri green mottle mosaic virus (KGMMV) pada Melon (Cucumis melo L.) Faculty of Biology, UGM, pp. 67-79. 


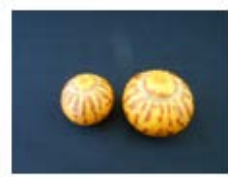

१ NO3

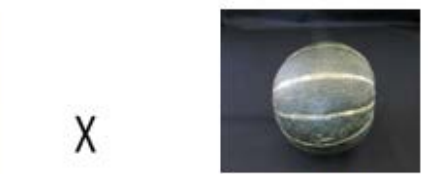

\& MR5

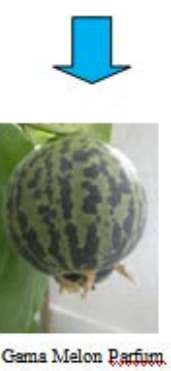

Figure 1. Pedigree of Gama Melon Parfum

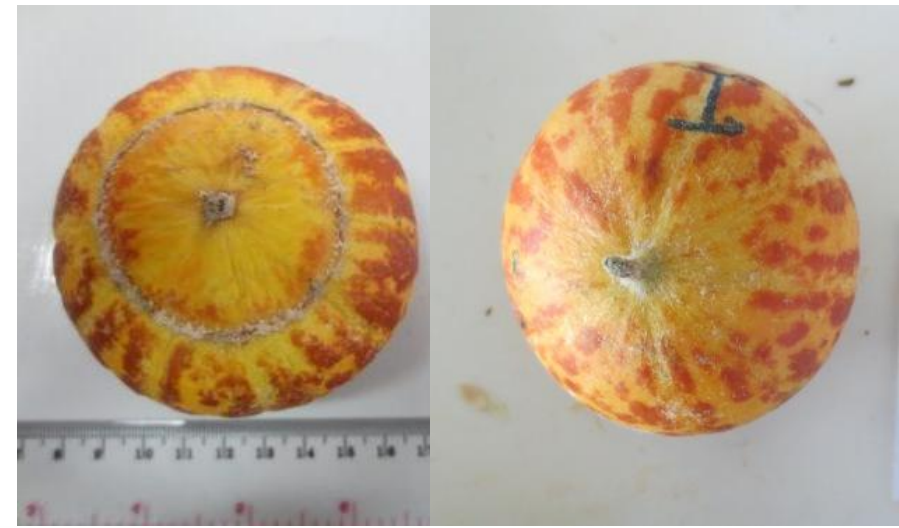

Figure 2. Gama Melon Parfum Cultivar, (A) Bottom; (B) Above

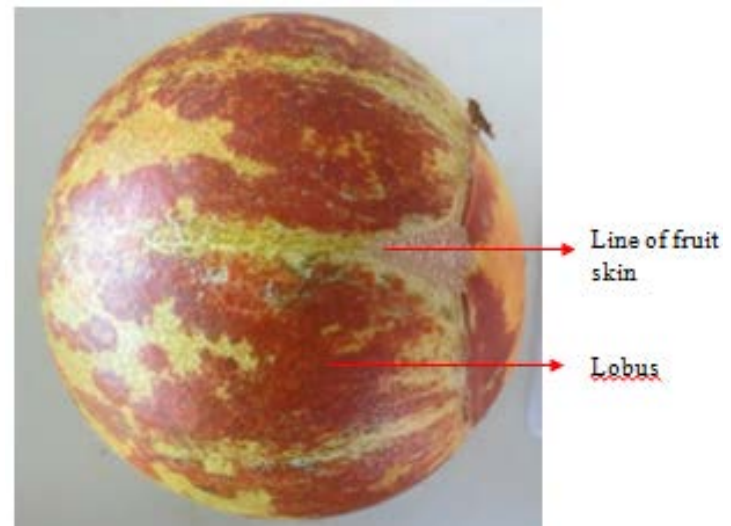

Figure 3. Gama Melon Parfum, see from side

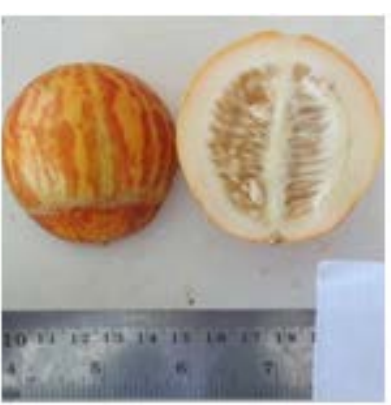

A

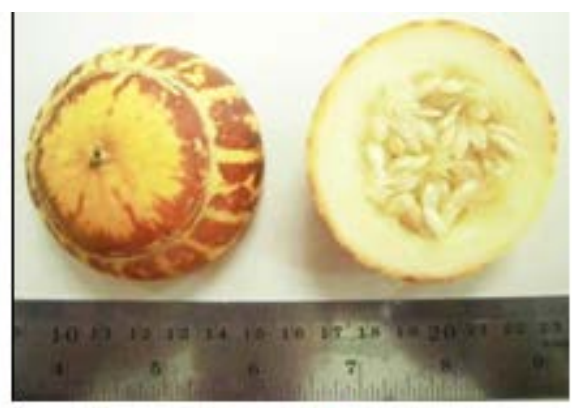

B

Figure 4. Gama Melon Parfum Cultivars, (A) Longitudinal; (B) Transversal 
TABLE 1.

Qualitative Characters of Gama Melon Parfume

\begin{tabular}{ccc}
\hline \hline No & Qualitative Phenotype Characters & Gama Melon Parfum \\
\hline $\mathbf{1}$ & Shape of fruit & Oblate \\
$\mathbf{2}$ & Size & Small \\
$\mathbf{3}$ & Netted & Not netted \\
$\mathbf{4}$ & Colour of skin fruit & Orange \\
$\mathbf{5}$ & Colour of flesh fruit & White \\
$\mathbf{6}$ & Texture & Cruncy \\
$\mathbf{7}$ & Taste & Bitter \\
$\mathbf{8}$ & Aroma & Strong fragnant \\
$\mathbf{9}$ & Turbin & have turbin \\
$\mathbf{1 0}$ & Lobus and longitudinal lines & $9-10$ \\
\hline \hline
\end{tabular}

TABLE 2.

QUANTITATIVE CHARACTERS OF GAMA MELON PARFUME

\begin{tabular}{|c|c|c|}
\hline No & Quantitative Characters & "Gama Melon Parfum (Average) \\
\hline 1 & Weight & 160 gram \\
\hline 2 & Circumference & $21,8 \mathrm{~cm}$ \\
\hline 3 & Horizontal Diameter & $6,89 \mathrm{~cm}$ \\
\hline 4 & Vertical Diameter & $6,44 \mathrm{~cm}$ \\
\hline 5 & Thick skin & $1 \mathrm{~mm}$ \\
\hline 6 & Thick flesh & $1,06 \mathrm{~cm}$ \\
\hline 7 & The number of seed & $200-300$ \\
\hline 8 & Weight of 100 seed & 1,74 gram \\
\hline 9 & Harvest time & 63-65 day after cultivate \\
\hline 10 & Storage time & 17 days \\
\hline
\end{tabular}

